\title{
RANCANG BANGUN DAN PENGUJIAN KUALITAS APLIKASI WEB E-RECRUITMENT BERDASARKAN ISO/IEC 9126 PADA SUATU PERUSAHAAN PEMBIAYAAN DI INDONESIA
}

\author{
Dedi Iskandar ${ }^{1}$, Dina Indarti ${ }^{2}$ \\ ${ }^{1}$ Program Studi Perangkat Lunak Sistem Informasi, Fakultas Program Magister Teknologi dan Rekayasa \\ Universitas Gunadarma \\ Jalan Kenari Nomor 13 Jakarta Pusat, 10430 \\ ${ }^{2}$ Program Studi Teknik Informatika, Fakultas Teknologi Industri \\ Universitas Gunadarma \\ Jalan Margonda Raya Nomor 100, Depok, Jawa Barat, 16424 \\ Idiiskandarde@gmail.com,2dina.indarti@staff.gunadarma.ac.id
}

Abstrak- Penelitian ini bertujuan untuk merancang, membuat, dan menguji kualitas aplikasi web e-recruitment pada suatu perusahaan pembiayaan di Indonesia berdasarkan ISO/IEC 9126. Metode yang digunakan dalam penelitian ini adalah Research and Development (R\&D) meliputi identifikasi potensi dan masalah, analisis kebutuhan dan pengumpulan data, desain aplikasi, implementasi, validasi aplikasi, revisi aplikasi, dan uji coba aplikasi. Pembuatan aplikasi web $e$ recruitment menggunakan LAMP (Linux, Apache, MySQL, PHP). Pengujian kualitas aplikasi berdasarkan 6 faktor yaitu functionality, reliability, efficiency, usability, maintainability, dan portability. Faktor functionality diuji menggunakan black box testing. Faktor efficiency diuji menggunakan GT Metrix (Yslow) dan Page Speed Insight. Faktor reliability diuji menggunakan stress testing (LoadStrom, LoadImpact, dan WAPT 8.1). Faktor maintainability diuji berdasarkan aspek instrumentation, consistency, dan simplicity. Faktor portability diuji menggunakan beberapa web browser dan faktor usability menggunakan Computer System Usability Questionnaire. Berdasarkan hasil penelitian yang telah dilakukan, aplikasi web e-recruitment mampu berjalan dengan baik dengan beberapa revisi dari ahli rekrutmen dan ahli pemrograman. Hasil pengujian kualitas aplikasi berdasarkan ISO/IEC 9126 telah memenuhi standar faktor kualitas aplikasi dari faktor functionality, reliability, usability, maintainability, dan portability. Faktor efficiency masih belum memenuhi standar faktor kualitas aplikasi.

Kata Kunci-Aplikasi Web, E-Recruitment, ISO/IEC 9126, Kualitas Perangkat Lunak, Research \& Development (R\&D)

Abstract-This research aims to design, create, and test the quality of e-recruitment web applications at a financing company in Indonesia based on ISO/IEC 9126. Methods used in this study are Research and Development (R\&D) including potential identification and problems, analysis and data collection, application design, implementation, application validation, application revision, and application trials. E-Recruitment web application was created using LAMP (Linux, Apache, MySQL, PHP). Application quality testing based on 6 factors namely functionality, reliability, efficiency, usability, maintainability, and portability. Functionality factor was tested using black box testing. The efficiency factor was tested using GT Metrix (Yellow) and PageSpeed Insight. The reliability factor was tested using stress testing (LoadStrom, LoadImpact, and WAPT 8.1). The maintainability factor was tested based on instrumentation, consistency, and simplicity aspects. The portability factor was tested using multiple web browsers, and usability factor using Computer System Usability Questionnaire. Based on the results of the research that has been done, e-recruitment web application is able to run well with some revisions from recruitment experts and programming experts. Application test results based on ISO/IEC 9126 have met the application quality factor standards of functionality, reliability, usability, maintainability, and portability. The efficiency factor still does not meet the application quality factor standards.

Keywords-Web application, E-Recruitment, ISO/IEC 9126, Software Quality, Research \& Development (R\&D)

\section{PENDAHULUAN}

Manajemen Sumber Daya Manusia (MSDM) merupakan perencanaan, pengorganisasian, pelaksanaan, pengawasan terhadap pengadaan, pengembangan, dan pemisahan tenaga kerja dalam rangka mencapai tujuan organisasi. Salah satu manfaat dari teknologi informasi yang dapat diaplikasikan dalam perusahaan adalah aplikasi rekrutmen daring $(e-$ recruitment) yaitu suatu aplikasi penarikan calon tenaga kerja baru bagi perusahaan secara daring menggunakan media internet [1]. 
Aspek perekrutan SDM mulai mendapatkan perhatian khusus, karena proses perekrutan yang tidak sesuai dengan kebutuhan dapat menghambat laju perkembangan dalam suatu perusahaan. Evolusi peradaban manusia bertransformasi dan membutuhkan tenaga kerja terampil yang dapat membawa perusahaan ke arah lebih baik yang terjadi secara signifikan [2]. Adanya daya saing yang meningkat dalam bidang perekrutan, maka perusahaan harus mengembangkan strategi perekrutan dan memperluas jangkauan periklanan [3].

Penyebab organisasi bertransformasi dari metode perekrutan tradisional ke e-recruitment antara lain citra organisasi menjadi meningkat dengan adanya kehadiran web dan penggunaan internet, biaya perekrutan lebih rendah, mengurangi biaya kerja, beban administrasi, dan kemampuan untuk menyebarluaskan informasi [4]. Dampak yang nyata mampu ditimbulkan oleh $e$-recruitment terhadap proses perekrutan secara menyeluruh, dengan terjadinya perubahan terhadap urutan, pembagian tugas, dan pengerjaan sejumlah tugas yang berulang [5].

Saat ini, perangkat lunak bukan merupakan hal asing dalam dunia internet. Dalam memenuhi perangkat lunak yang berkualitas, beberapa model evaluasi perangkat lunak telah banyak dikembangkan dalam penelitian, seperti panduan desain perangkat lunak, teknik penilaian usability dan model Quality Assurance (QA). Namun, standar evaluasi kualitas perangkat lunak masih terbatas, kebanyakan penelitian hanya berfokus pada karakteristik fitur usability [6].

Evaluasi kualitas sebuah perangkat lunak sangat penting untuk memastikan apakah perangkat lunak tersebut memenuhi harapan dan tujuan untuk pengguna yang dimaksud. Selain itu, hasil evaluasi akan membantu dalam mengetahui bagian mana yang perlu dilakukan modifikasi untuk pengembangan perangkat lunak tersebut. Evaluasi kualitas perangkat lunak dapat dilakukan dalam berbagai macam cara, salah satunya adalah model evaluasi kepuasan pengguna. Kepuasan tidak hanya dilihat dari desain perangkat lunak yang menarik, tetapi apakah pengguna yang menggunakan perangkat lunak tersebut menemukan apa yang dicari secara cepat, mudah, dan sesuai [7].

Suatu perusahaan pembiayaan di Indonesia telah melakukan proses penerimaan karyawan secara mandiri atau tidak menggunakan jasa perusahaan outsourcing. Dalam proses penerimaan karyawan, perusahaan pembiayaan tersebut menggunakan bursa kerja dan situs lowongan kerja sehingga prosesnya cukup panjang. Selain itu, staf bagian perekrutan karyawan tidak jarang dihadapkan pada keadaan jumlah lowongan yang terbatas serta calon karyawan yang berminat dan memenuhi persyaratan administrasi jumlahnya berlipat dari yang diperlukan. Salah satu solusi dalam mengatasi permasalahan tersebut yaitu menggunakan aplikasi web e-recruitment.

Pengujian kualitas perangkat lunak dapat dilakukan dengan berbagai model seperti McCall, Boehm,
Dromey, FURPS, dan ISO/IEC 9126. Pada penelitian ini digunakan model ISO/IEC 9126. ISO/IEC 9126 merupakan sebuah standar internasional yang diterbitkan oleh ISO dan IEC untuk mengevaluasi dan menetapkan kualitas sebuah produk perangkat lunak. ISO/IEC 9126 merupakan model kualitas yang paling lengkap berdasarkan kriteria dan strukturnya, sehingga lebih baik dibandingkan keempat model kualitas lainnya. ISO/IEC 9126 terdiri atas enam karakteristik dalam software quality yaitu functionality, reliability, usability, efficiency, maintainability, dan portability [8].

Beberapa penelitian telah menggunakan ISO/IEC 9126 dalam mengevaluasi kualitas perangkat lunak. Penelitian [9] membahas mengenai penerapan ISO/IEC 9126 dalam pengujian kualitas perangkat lunak pada $e$ book. Penelitian tersebut tidak menguji kualitas perangkat lunak dari faktor maintainability, functionality, reliability, efficiency, dan usability. Penelitian [10] membahas mengenai evaluasi kualitas perangkat lunak menggunakan ISO/IEC 9126-4 Quality In Use pada aplikasi FILKOM. Pada penelitian tersebut tidak menguji faktor functionality, reliability, usability, efficiency, maintainability, dan portability. Penelitian [11] membahas mengenai evaluasi kualitas aplikasi web pemantau menggunakan model pengujian perangkat lunak ISO/IEC 9126. Pada penelitian tersebut tidak menguji maintainability dan portability.

Pada penelitian ini dilakukan perancangan, pembuatan dan pengujian aplikasi web e-recruitment pada suatu perusahaan pembiayaan di Indonesia. Pembuatan aplikasi web e-recruitment menggunakan LAMP (Linux, Apache, MySQL, PHP) yaitu dengan sistem operasi Linux, web server Apache, basis data MySQL, dan bahasa pemrograman PHP. Pengujian aplikasi web e-recruitment berdasarkan ISO/IEC 9126 yang terdiri dari enam faktor kualitas yaitu functionality, reliability, usability, efficiency, maintainability, dan portability.

\section{METODE PENELITIAN}

Penelitian ini dilakukan menggunakan metode Research and Development (R\&D) [12]. Tahapan pada penelitian ini dapat dilihat pada Gbr. 1 . 


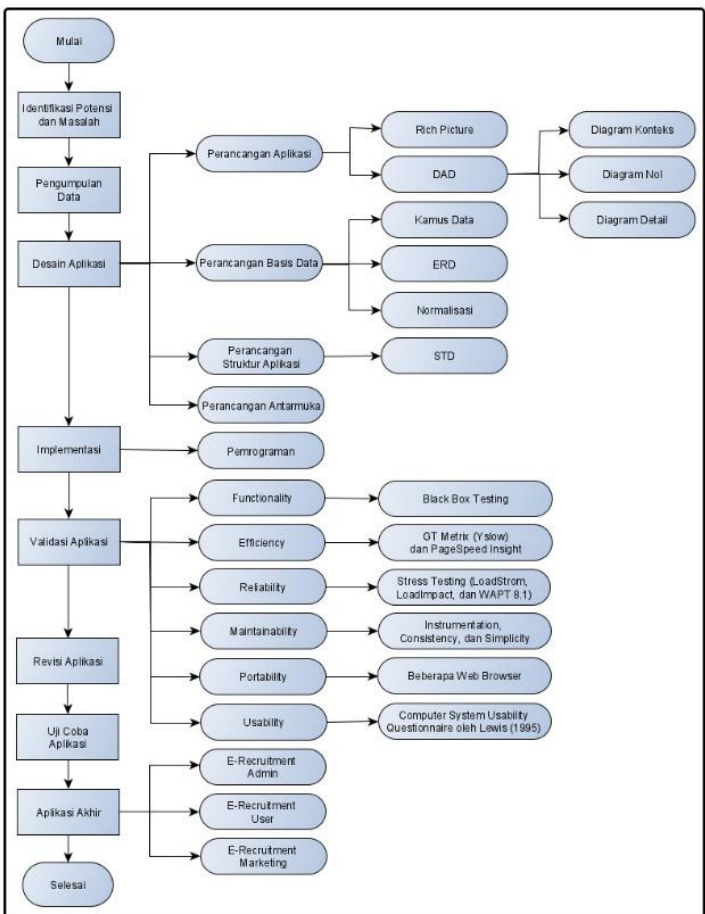

Gbr. 1 Skema penelitian

\section{A. Identifikasi Potensi dan Masalah}

Identifikasi potensi dan masalah dalam penelitian ini adalah permasalahan pada sistem penerimaan karyawan di suatu perusahaan pembiayaan di Indonesia yang masih menggunakan cara konvensional yaitu melalui bursa kerja dan situs lowongan kerja. Hal tersebut menyebabkan proses penerimaan karyawan cukup panjang. Selain itu, staf bagian perekrutan karyawan juga dihadapkan pada masalah jumlah lowongan yang terbatas tetapi calon karyawan yang berminat dan memenuhi persyaratan administrasi jumlah berlipat dari yang diperlukan. Oleh karena itu, pada penelitian ini dibuat aplikasi web untuk memudahkan proses rekrutmen baik bagi perusahaan maupun bagi pelamar.

Setelah pembuatan aplikasi web e-recruitment, permasalahan yang muncul yaitu apakah kualitas aplikasi web e-recruitment yang dibuat sudah memenuhi tujuan dari pembuatan aplikasi tersebut. Oleh karena itu diperlukan suatu pengujian kualitas aplikasi web e-recruitment.

\section{B. Analisis Kebutuhan dan Pengumpulan Data}

Analisis kebutuhan yang dilakukan pada tahap ini adalah analisis terhadap kebutuhan perangkat lunak dan perangkat keras dalam pembuatan aplikasi web $e$ recruitment. Analisis kebutuhan juga dilakukan terhadap kebutuhan fitur pada aplikasi web. Penelitian ini dilakukan dari bulan Februari 2020 sampai bulan Agustus 2020 di suatu perusahaan pembiayaan di Indonesia. Pengumpulan data dilakukan dengan melakukan studi pustaka, wawancara, observasi, dan kuesioner.

\section{Desain Aplikasi}

Desain aplikasi yang pertama adalah perancangan aplikasi web e-recruitment menggunakan rich picture untuk menggambarkan sistem penerimaan karyawan yang sedang berjalan dan sistem penerimaan karyawan usulan serta DAD untuk menggambarkan aliran data. Kedua adalah membuat perancangan basis data $e$ recruitment menggunakan kamus data, Entity Relationship Diagram (ERD), dan normalisasi. Ketiga adalah membuat perancangan struktur e-recruitment menggunakan State Transition Diagram (STD). Keempat adalah perancangan antarmuka e-recruitment untuk menggambarkan tampilan dari aplikasi web $e$ recruitment yang dibuat.

\section{Implementasi}

Dalam proses implementasi mulai dilakukan pembuatan kode program menggunakan LAMP (Linux, Apache, MySQL, PHP) dan konfigurasi agar program dapat berjalan.

\section{E. Validasi Aplikasi}

Proses validasi atau pengujian aplikasi dilakukan terhadap 6 faktor yaitu functionality, reliability, usability, efficiency, maintainability, dan portability. Validasi faktor functionality menggunakan black box testing. Validasi faktor efficiency menggunakan GT Metrix (Yslow) dan Page Speed Insight. Validasi faktor reliability menggunakan stress testing (LoadStrom, LoadImpact, dan WAPT 8.1). Validasi faktor maintainability berdasarkan aspek instrumentation, consistency, dan simplicity. Validasi faktor portability menggunakan beberapa web browser, serta validasi faktor usability menggunakan Computer System Usability Questionnaire [13].

\section{F. Revisi Aplikasi}

Revisi aplikasi dilakukan oleh tim HR recruitment dan tim pemrograman yang memberikan saran-saran terhadap aplikasi web.

\section{G. Uji Coba Aplikasi}

Setelah aplikasi web divalidasi dan direvisi, maka langkah selanjutnya adalah menguji aplikasi web. Uji coba aplikasi ini dilakukan oleh tim HR recruitment, tim marketing, dan beberapa pelamar untuk menguji aplikasi web e-recruitment.

\section{PEMBAHASAN}

\section{A. Analisis Sistem yang Sedang Berjalan}

1. Divisi yang membutuhkan karyawan mengisi Formulir Permohonan Tambahan Karyawan (FPTK) melalui Human Resource Information System (HRIS) ke bagian HR Recruitment.

2. Setelah diajukan permohonan tersebut harus ada persetujuan dari kepala divisi dan HR Recruitment, kemudian dianalisis apakah pengajuan tersebut sesuai dengan manpower planning untuk posisi tersebut atau tidak. 
3. Setelah FPTK disetujui oleh kepala divisi, HR Recruitment akan memulai proses seleksi untuk pemenuhan karyawan yang dibutuhkan.

4. Proses awal dari rekrutmen adalah mencari kandidat yang sesuai dengan kualifikasi yang dibutuhkan seperti riwayat pendidikan, pengalaman kerja, pengalaman organisasi, keahlian, dan surat kelengkapan lainnya.

5. Kemudian kandidat yang sudah lolos seleksi administrasi akan diundang untuk mengikuti tahap selanjutnya yaitu psikotes.

6. Kandidat yang lolos psikotes kemudian akan diundang kembali untuk mengikuti wawancara HR dan user.

7. Kandidat yang lolos akan diproses untuk negosiasi gaji dan Medical Check-Up (MCU) yang dilakukan oleh HR Compensation and Benefit (Comben).

8. Jika calon karyawan sudah lolos dalam MCU, bagian HR Compensation and Benefit (Comben) melakukan kesepakatan dengan calon karyawan.

Flowchart sistem penerimaan karyawan pada perusahaan yang sedang berjalan ditunjukkan pada Gbr. 2.

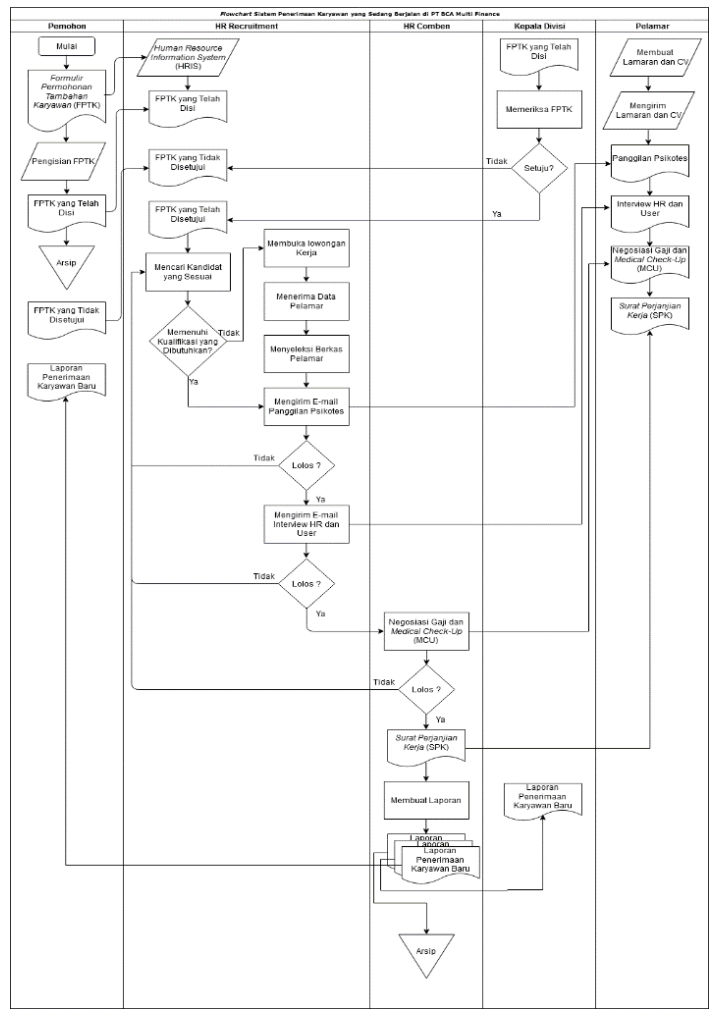

Gbr. 2 Flowchart sistem penerimaan karyawan yang sedang berjalan

B. Prosedur Sistem Penerimaan Karyawan yang Diusulkan

1. Pemohon yang membutuhkan karyawan mengisi Form Permintaan Tambahan Karyawan (FPTK) melalui Human Resource Information System (HRIS) ke bagian HR Recruitment.
2. Setelah diajukan permohonan tersebut harus ada persetujuan dari kepala divisi dan HR Recruitment, kemudian dianalisis apakah pengajuan tersebut sesuai dengan manpower planning untuk posisi tersebut atau tidak.

3. Setelah FPTK disetujui oleh kepala divisi, HR Recruitment akan memulai proses seleksi untuk pemenuhan karyawan yang dibutuhkan.

4. Proses awal dari rekrutmen adalah mencari kandidat yang sesuai dengan kualifikasi yang dibutuhkan seperti riwayat pendidikan, pengalaman kerja, pengalaman organisasi, keahlian, dan surat kelengkapan lainnya yang didapat dari jobstreet atau jobfair.

5. HR Recruitment memasukkan data pelamar yang lolos dalam seleksi berkas ke dalam e-recruitment admin.

6. Pelamar yang lolos dalam seleksi berkas mendapatkan username dan password untuk login di e-recruitment pelamar.

7. Setelah pelamar login, pelamar wajib mengisi data diri pada e-recruitment pelamar.

8. HR Recruitment memberikan pilihan jadwal psikotes untuk pelamar yang lolos seleksi berkas.

9. Pelamar memilih tanggal untuk pelaksanaan psikotes.

10. Pelamar melaksanakan psikotes pada tanggal yang telah dipilih.

11.HR Recruitment memberikan pilihan jadwal interview HR dan user untuk pelamar yang lolos psikotes.

12. Pelamar memilih tanggal untuk pelaksanaan interview HR dan user.

13. Pelamar melaksanakan interview HR dan user pada tanggal yang telah dipilih.

14. HR Recruitment memberikan pilihan jadwal MCU untuk pelamar yang lolos intervies HR dan user.

15. Pelamar memilih tanggal untuk pelaksanaan Medical Check-Up (MCU).

16. Pelamar melaksanakan Medical Check-Up (MCU) pada tanggal yang telah dipilih. Pada hari yang bersamaan, HR Comben melakukan negosiasi gaji dengan pelamar.

17. HR Comben melakukan perjanjian kerja dengan pelamar dan membuat laporan penerimaan karyawan.

18. HR Comben memberikan laporan penerimaan karyawan kepada ketua divisi terkait.

Prosedur sistem penerimaan karyawan yang diusulkan ditunjukkan pada Gbr. 3. 
Page | 24

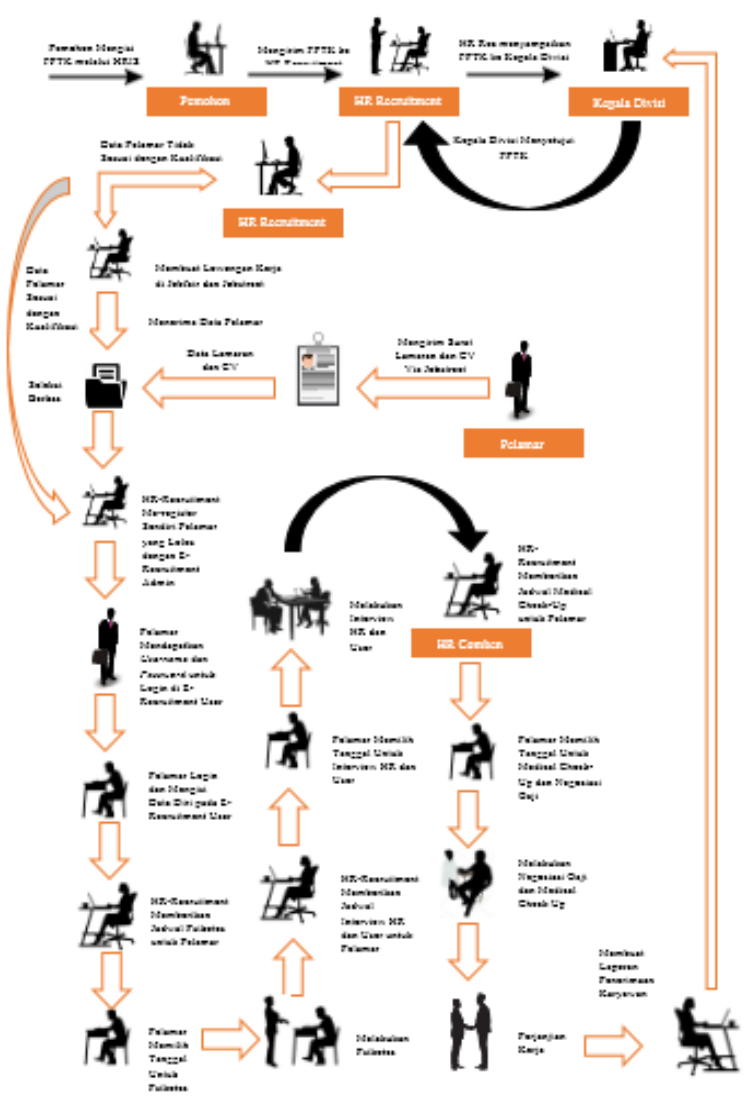

Gbr 3. Rich picture prosedur sistem yang diusulkan

\section{Hasil Tampilan Antarmuka E-Recruitment Admin}

Halaman login admin dapat dilihat pada Gbr. 4. Setelah dinyatakan berhasil login maka admin langsung masuk ke dalam tampilan home.

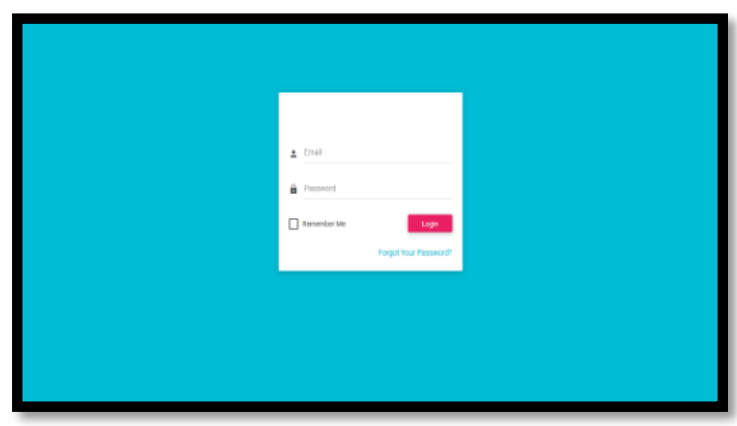

Gbr. 4 Halaman login admin

Halaman registrasi pelamar adalah halaman untuk mendaftarkan pelamar yang lolos kualifikasi berkas. Halaman registrasi pelamar dapat dilihat pada Gbr. 5.

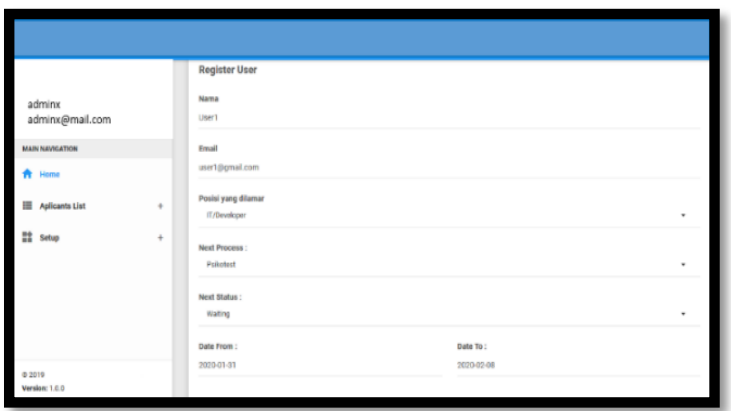

Gbr. 5 Halaman registrasi pelamar

Halaman daftar lowongan kerja adalah halaman daftar lowongan yang ada di perusahaan. Dalam halaman ini terdiri dari beberapa posisi yang dibutuhkan oleh perusahaan. Halaman daftar lowongan kerja dapat dilihat pada Gbr. 6.

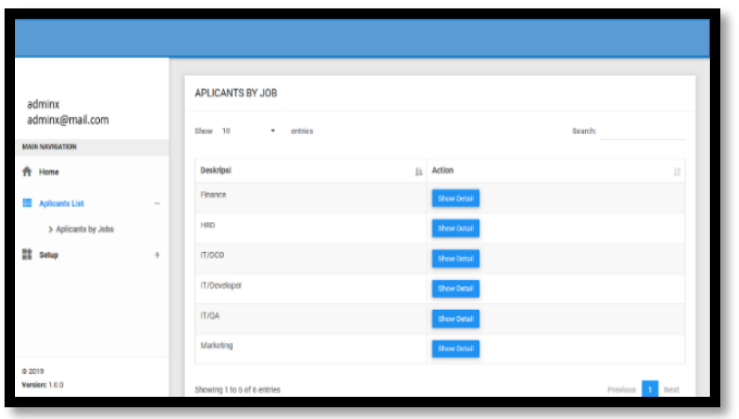

Gbr. 6 Halaman daftar lowongan kerja

Halaman aplicants job adalah halaman yang menampilkan daftar posisi pekerjaan. Halaman aplicants by job dapat dilihat pada Gbr. 7 .

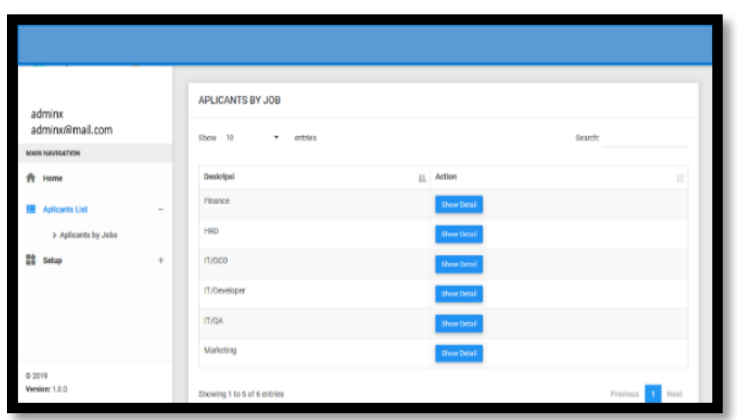

Gbr. 7 Halaman aplicants by job

Halaman aplicants list adalah halaman yang menampilkan daftar yang melamar posisi pekerjaan tertentu. Halaman aplicants list dapat dilihat pada Gbr. 8. 


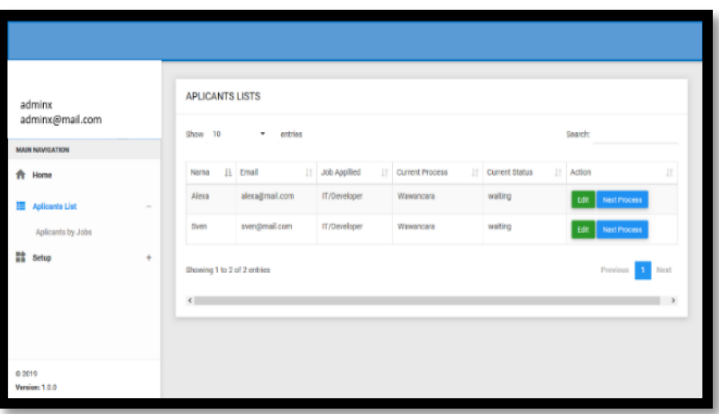

Gbr. 8 Halaman aplicants list

Halaman edit aplicants adalah halaman untuk mengubah current process ke tahap selanjutnya. Di current process tersebut terdapat 3 tahap yaitu psikotes, interview HR dan user, dan Medical Check-Up (MCU). Halaman edit aplicants (wawancara) dapat dilihat pada Gbr. 9.

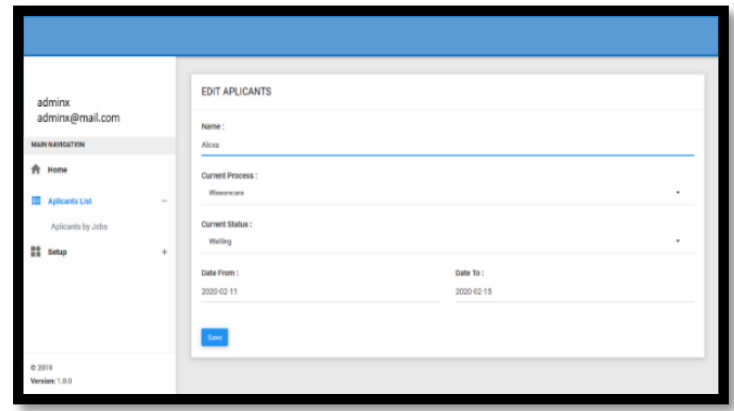

Gbr. 9 Halaman edit aplicants (wawancara)

Halaman data job type adalah halaman untuk menampilkan daftar pekerjaan yang ada di perusahaan. Halaman data job type dapat dilihat pada Gbr. 10.

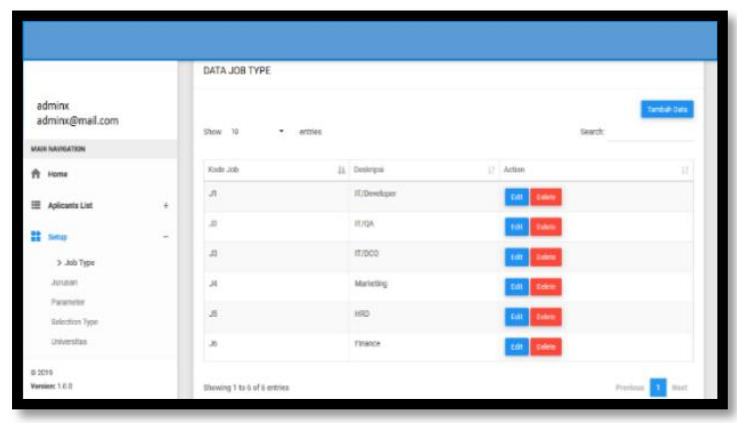

Gbr. 10 Halaman data job type

Halaman data jurusan adalah halaman untuk menampilkan daftar jurusan. Halaman data jurusan dapat dilihat pada Gbr. 11.

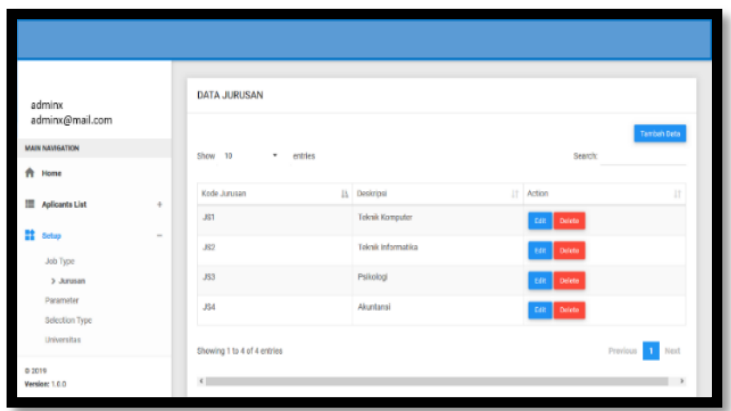

Gbr. 11 Halaman data jurusan

Halaman data selection type adalah halaman untuk menampilkan daftar tahap seleksi. Halaman data selection type dapat dilihat pada Gbr. 12.

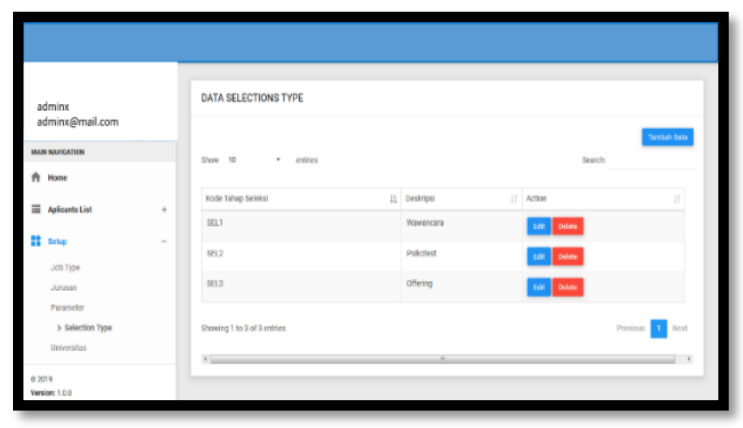

Gbr. 12 Halaman data selection type

Halaman data universitas adalah halaman untuk menampilkan daftar universitas. Halaman data universitas dapat dilihat pada Gbr. 13.

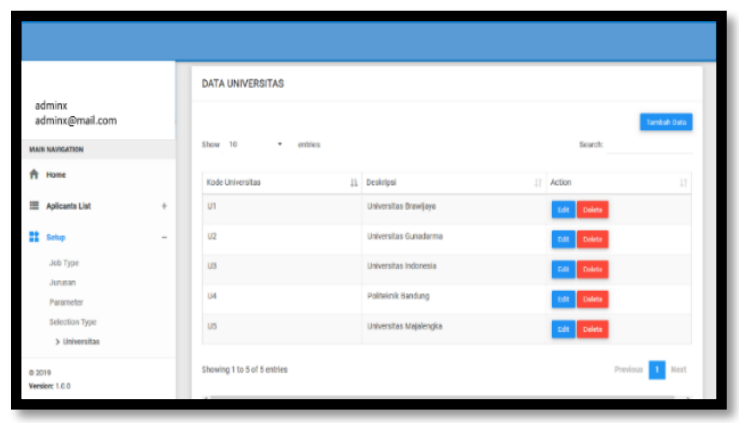

Gbr. 13 Halaman data universitas

\section{Hasil Tampilan Antarmuka E-Recruitment Pelamar}

Halaman registrasi pelamar adalah halaman untuk melakukan registrasi sebelum pelamar melakukan tracking. Halaman registrasi dapat dilihat pada Gbr. 14. 

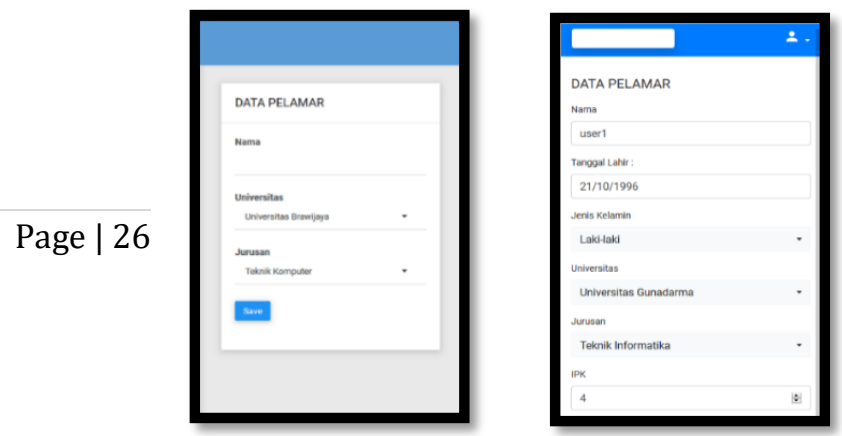

Gbr. 14 Halaman registrasi pelamar

Halaman tracking pelamar adalah halaman untuk memudahkan pelamar untuk memilih jadwal psikotes, wawancara HR dan user, MCU yang tersedia. Halaman tracking pelamar dapat dilihat pada Gbr. 15.
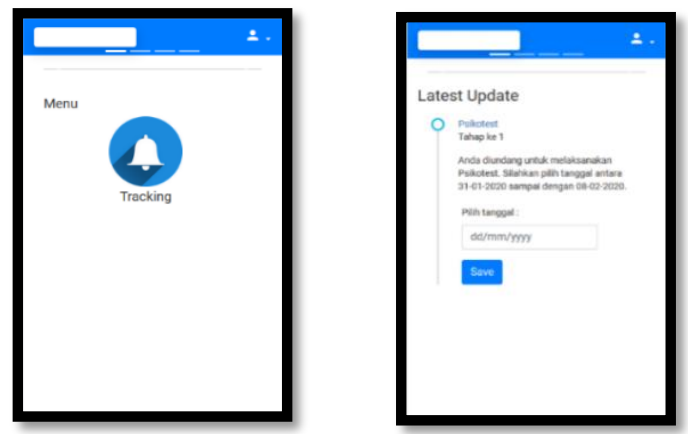

Gbr. 15 Halaman tracking pelamar

\section{E. Hasil Tampilan Antarmuka E-Recruitment Marketing}

Halaman dashboard marketing adalah halaman untuk menampilkan gambar iklan perusahaan yang telah diunggah pada aplikasi web e-recruitment marketing. Halaman dashboard marketing dapat dilihat pada Gbr. 16.

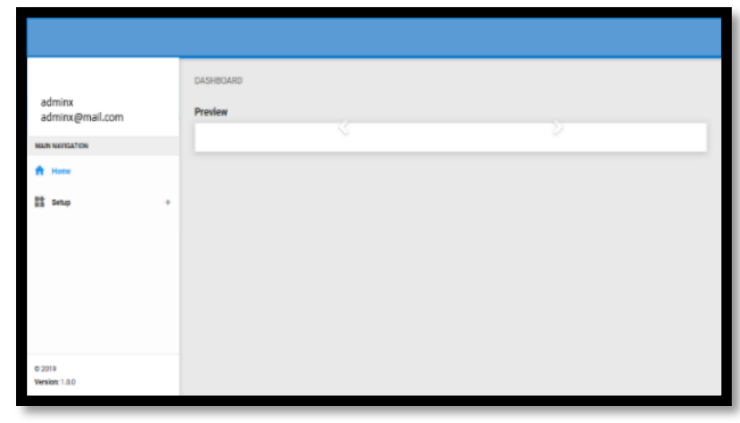

Gbr. 16 Halaman dashboard marketing

Halaman master adverts adalah halaman untuk mengunggah gambar iklan perusahaan oleh marketing. Halaman master adverts dapat dilihat pada Gbr. 17.

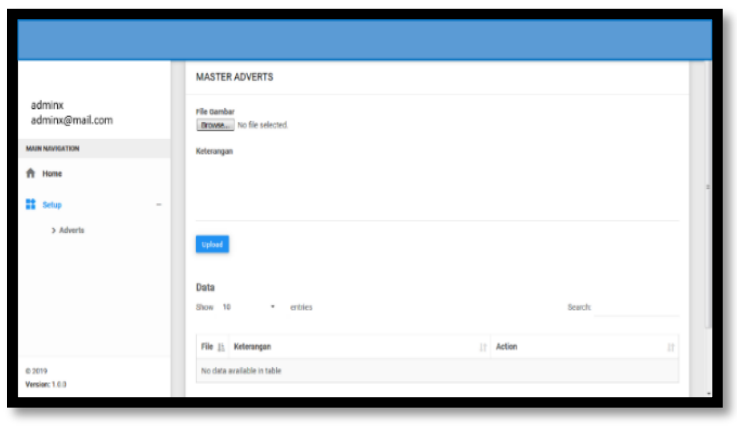

Gbr. 17 Halaman master adverts

\section{F. Pengujian Aplikasi}

1. Pengujian Faktor Functionality

TABEL 1

ANALISIS DATA PENGUJIAN FUNCTIONALITY

\begin{tabular}{|c|c|c|c|}
\hline Pertanyaan & $\begin{array}{c}\text { Skor } \\
\text { Total }\end{array}$ & $\begin{array}{c}\text { Skor } \\
\text { Maksimal }\end{array}$ & $\begin{array}{c}\text { Persentase } \\
(\boldsymbol{\%})\end{array}$ \\
\hline $1,3-33,35$ & 8 & 8 & 100 \\
\hline 2 & 5 & 8 & 62,5 \\
\hline 34 & 2 & 8 & 25 \\
\hline TOTAL & 271 & 280 & 96,79 \\
\hline
\end{tabular}

Berdasarkan analisis data pengujian functionality pada Tabel 1, maka diperoleh persentase $96,79 \%$ dari pengujian functionality. Nilai tersebut kemudian dikonversi ke data kualitatif dan berdasarkan skala penilaian produk media, dari skor persentase yang didapat maka kualitas perangkat lunak dari sisi functionality mempunyai skala "Sangat Tinggi" dan telah memenuhi faktor functionality.

\section{Pengujian Faktor Reliability}

Berdasarkan Gbr. 18, hasil Test Statistics dan Test Information menggunakan tool dari LoadStorm menunjukkan dari 2178 total requests, 2178 sukses sementara 0 error. Ini artinya aplikasi web $e$ recruitment memiliki persentase reliability $100 \%$ atau sangat tinggi.

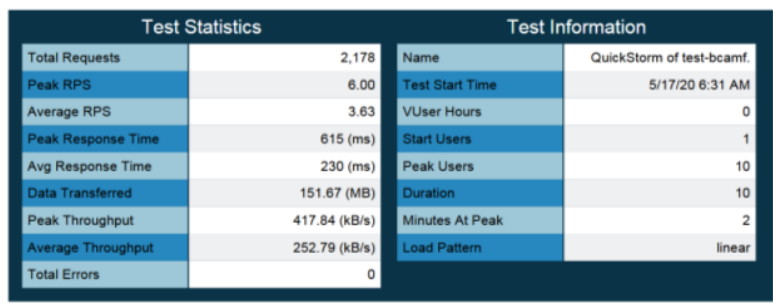

Gbr. 18 Hasil test statistics dan test information

Berdasarkan Gbr. 19, hasil performance overview menggunakan tool dari LoadImpact menunjukkan dari 4,7K total requests, 4,7K sukses sementara 0 failures. Ini artinya dari sisi reliability, website penilaian kualitas aplikasi web e-recruitment ini memiliki persentase reliability $100 \%$ atau sangat tinggi. 


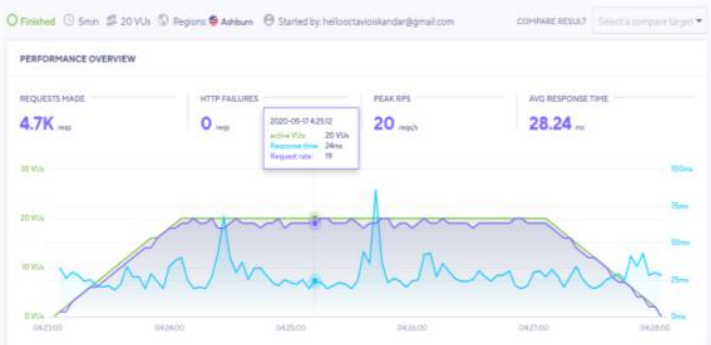

Gbr. 19 Hasil performance overview dari tool LoadImpact

Berdasarkan Tabel 2 hasil pengujian faktor reliability menunjukkan aplikasi penilaian kualitas aplikasi web e-recruitment tersebut memiliki kualitas reliability yang sangat tinggi.

TABEL 2

PENGUJIAN RELIABILITY DENGAN WAPT 8.1

\begin{tabular}{|c|c|c|c|c|c|}
\hline No. & Metrik & Sukses & Gagal & Persentase & Hasil \\
\hline 1. & Sessions & 1 & 0 & $100 \%$ & $\begin{array}{c}\text { Sangat } \\
\text { Tinggi }\end{array}$ \\
\hline 2. & Pages & 17 & 0 & $100 \%$ & $\begin{array}{c}\text { Sangat } \\
\text { Tinggi }\end{array}$ \\
\hline 3. & Hits & 54 & 0 & $100 \%$ & $\begin{array}{c}\text { Sangat } \\
\text { Tinggi }\end{array}$ \\
\hline
\end{tabular}

\section{Pengujian Faktor Usability}

Berdasarkan Tabel 3, persebaran data berdasarkan rata-rata per item menunjukkan bahwa rata-rata terendah berada di angka 4,9. Nilai rata-rata di atas 4,5 hingga 5,5 masuk ke dalam kategori "Layak" dan nilai rata-rata di atas 5,5 masuk ke dalam kategori "Sangat Layak". Hal ini berarti bahwa 17 dari 19 item berada pada kategori "Layak" dan sisanya yaitu 2 dari 19 item berada pada kategori "Sangat Layak". Melalui hasil rata-rata pengujian faktor usability berdasarkan keseluruhan item dapat disimpulkan bahwa aplikasi ini "Layak" digunakan sebagai aplikasi web e-recruitment.

TABEL 3

DATA HASIL PENGUJIAN FAKTOR USABILITY

\begin{tabular}{|c|c|c|c|c|}
\hline \multicolumn{2}{|c|}{ Score Name } & Item & Average & Kategori \\
\hline \multirow{8}{*}{ SYSUSE } & \multirow{19}{*}{$\begin{array}{l}O \\
V \\
E \\
R \\
A \\
L \\
L\end{array}$} & P 1 & 5,5 & Layak \\
\hline & & P 2 & 5,6 & Sangat Layak \\
\hline & & P 3 & 5,2 & Layak \\
\hline & & $\mathrm{P} 4$ & 5,5 & Layak \\
\hline & & P 5 & 5,5 & Layak \\
\hline & & P 6 & 5,3 & Layak \\
\hline & & P 7 & 5,4 & Layak \\
\hline & & P 8 & 5,3 & Layak \\
\hline \multirow{7}{*}{$\begin{array}{l}I N F O- \\
Q U A L\end{array}$} & & P 9 & 5,3 & Layak \\
\hline & & P 10 & 5,4 & Layak \\
\hline & & P 11 & 5,3 & Layak \\
\hline & & P 12 & 5,4 & Layak \\
\hline & & P 13 & 5,3 & Layak \\
\hline & & P 14 & 5,4 & Layak \\
\hline & & $\mathrm{P} 15$ & 4,9 & Layak \\
\hline \multirow{4}{*}{$\begin{array}{c}\text { INTER- } \\
Q U A L\end{array}$} & & $\mathrm{P} 16$ & 5,3 & Layak \\
\hline & & P 17 & 5,7 & Sangat Layak \\
\hline & & P 18 & 5,3 & Layak \\
\hline & & P 19 & 5,1 & Layak \\
\hline
\end{tabular}

Distribusi hasil pengujian faktor usability berdasarkan score name dapat dilihat pada Gbr. 20. Diagram menunjukkan bahwa penilaian system usefulness memiliki distribusi rata-rata sebesar 5,41. Rata-rata tersebut masuk ke dalam kategori "Layak". Information quality memiliki distribusi penilaian dengan rata-rata 5,29 dan masuk ke dalam kategori "Layak". Interface quality memperoleh penilaian dengan rata-rata 5,43 dan masuk ke dalam kategori "Layak". Hasil pengujian faktor usability secara overall mencapai rata-rata 5,3 dengan kategori "Layak". Oleh karena itu, dapat disimpulkan bahwa aplikasi web e-recruitment telah memenuhi kaidah software quality ditinjau dari faktor usability.

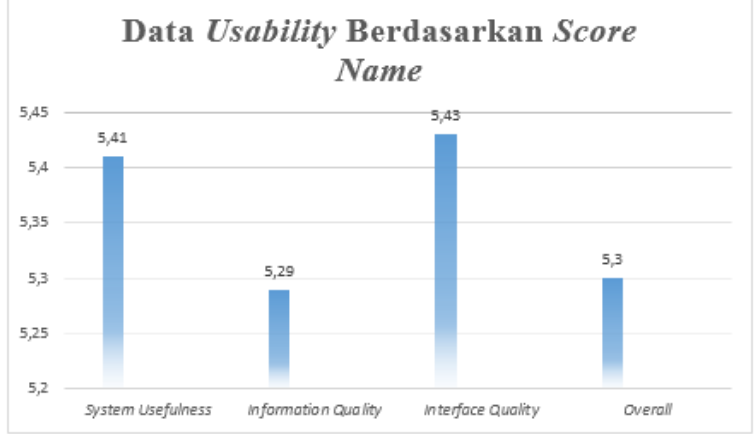

Gbr. 20 Diagram distribusi hasil pengujian faktor usability berdasarkan score name

\section{Pengujian Faktor Efficiency}

Berdasarkan Tabel 4, hasil pengujian efficiency dengan menggunakan GT Metrix (Yslow) menunjukkan rata-rata overall performance score 51 dengan grade D. Dengan demikian hasil pengujian efficiency dengan GT Metrix (Yslow) menunjukkan hasil "Kurang".

TABEL 4

OVERALL PERFORMANCE

\begin{tabular}{|c|l|c|c|}
\hline No. & \multicolumn{1}{|c|}{ Halaman } & Score & Grade \\
\hline \multicolumn{3}{|c|}{ Halaman E-Recruitment Admin } \\
\hline 1. & Halaman Login Admin & 51 & $\mathrm{D}$ \\
\hline 2. & $\begin{array}{l}\text { Halaman Home } \\
\text { (Dashboard) Admin }\end{array}$ & 51 & $\mathrm{D}$ \\
\hline 3. & $\begin{array}{l}\text { Halaman Aplicants } \\
\text { Admin }\end{array}$ & 51 & $\mathrm{D}$ \\
\hline 4. & $\begin{array}{l}\text { Halaman Job Type } \\
\text { Admin }\end{array}$ & 51 & $\mathrm{D}$ \\
\hline 5. & Halaman Majors Admin & 51 & $\mathrm{D}$ \\
\hline 6. & Halaman Params Admin & 51 & $\mathrm{D}$ \\
\hline 7. & $\begin{array}{l}\text { Halaman Selection Type } \\
\text { Admin }\end{array}$ & 51 & $\mathrm{D}$ \\
\hline 8. & $\begin{array}{l}\text { Halaman Universities } \\
\text { Admin }\end{array}$ & 51 & $\mathrm{D}$ \\
\hline \multicolumn{4}{|c|}{ Halaman E-Recruitment Pelamar } \\
\hline 1. & Halaman Login Pelamar & 51 & $\mathrm{D}$ \\
\hline 2. & $\begin{array}{l}\text { Halaman Formulir } \\
\text { Pelamar }\end{array}$ & 51 & $\mathrm{D}$ \\
\hline 3. & $\begin{array}{l}\text { Halaman Home } \\
\text { (Dashboard) Pelamar }\end{array}$ & 51 & $\mathrm{D}$ \\
\hline & \multicolumn{2}{|c|}{ Halaman E-Recruitment Marketing } \\
\hline
\end{tabular}




\begin{tabular}{|c|l|c|c|}
\hline 1. & $\begin{array}{l}\text { Halaman Login } \\
\text { Marketing }\end{array}$ & 51 & $\mathrm{D}$ \\
\hline 2. & $\begin{array}{l}\text { Halaman Home } \\
\text { (Dashboard) Marketing }\end{array}$ & 51 & $\mathrm{D}$ \\
\hline 3. & Halaman Adverst & 51 & $\mathrm{D}$ \\
\hline
\end{tabular}

Page | 28 Pengujian menggunakan PageSpeed Insight akan menunjukkan skor dari website jika diakses. Rentang skor adalah $0-100$. Tabel 5 menunjukkan hasil penilaian web aplikasi penilaian kualitas aplikasi web e-recruitment dengan menggunakan PageSpeed Insight.

TABEL 5

HASIL PENGUJIAN DENGAN PAGESPEED INSIGHT

\begin{tabular}{|c|c|c|c|}
\hline No. & Halaman & $\begin{array}{c}\text { Skor } \\
\text { Mobile }\end{array}$ & $\begin{array}{c}\text { Skor } \\
\text { Desktop }\end{array}$ \\
\hline \multicolumn{4}{|c|}{ E-Recruitment Admin } \\
\hline 1 & Melakukan login sistem & 62 & 78 \\
\hline 2 & $\begin{array}{l}\text { Melakukan register untuk } \\
\text { pelamar yang lolos } \\
\text { kualifikasi }\end{array}$ & 67 & 89 \\
\hline 3 & $\begin{array}{l}\text { Menampilkan daftar posisi } \\
\text { lowongan pekerjaan }\end{array}$ & 56 & 77 \\
\hline 4 & $\begin{array}{l}\text { Menampilkan daftar yang } \\
\text { melamar posisi pekerjaan } \\
\text { tertentu }\end{array}$ & 61 & 86 \\
\hline 5 & $\begin{array}{l}\text { Melanjutkan proses } \\
\text { pelamar ke tahap } \\
\text { selanjutnya }\end{array}$ & 70 & 85 \\
\hline 6 & $\begin{array}{l}\text { Menampilkan Data Job } \\
\text { Type }\end{array}$ & 72 & 90 \\
\hline 7 & Edit Data Job Type & 54 & 73 \\
\hline 8 & $\begin{array}{l}\text { Menambahkan Data Job } \\
\text { Type }\end{array}$ & 67 & 82 \\
\hline 9 & Delete Data Job Type & 78 & 79 \\
\hline 10 & $\begin{array}{l}\text { Menampilkan Data } \\
\text { Jurusan }\end{array}$ & 56 & 88 \\
\hline 11 & Edit Data Jurusan & 43 & 84 \\
\hline 12 & $\begin{array}{l}\text { Menambahkan Data } \\
\text { Jurusan }\end{array}$ & 65 & 76 \\
\hline 13 & Delete Data Jurusan & 56 & 78 \\
\hline 14 & $\begin{array}{l}\text { Menampilkan Data } \\
\text { Parameter }\end{array}$ & 66 & 87 \\
\hline 15 & Edit Data Parameter & 58 & 81 \\
\hline 16 & $\begin{array}{l}\text { Menambahkan Data } \\
\text { Parameter }\end{array}$ & 58 & 76 \\
\hline 17 & Delete Data Parameter & 67 & 84 \\
\hline 18 & $\begin{array}{l}\text { Menampilkan Data } \\
\text { Selections Type }\end{array}$ & 58 & 82 \\
\hline 19 & Edit Data Selections Type & 67 & 70 \\
\hline 20 & $\begin{array}{l}\text { Menambahkan Data } \\
\text { Selections Type }\end{array}$ & 53 & 80 \\
\hline 21 & $\begin{array}{l}\text { Delete Data Selections } \\
\text { Type }\end{array}$ & 56 & 79 \\
\hline 22 & $\begin{array}{l}\text { Menampilkan Data } \\
\text { Universitas }\end{array}$ & 61 & 88 \\
\hline 23 & Edit Data Universitas & 58 & 86 \\
\hline 24 & $\begin{array}{l}\text { Menambahkan Data } \\
\text { Universitas }\end{array}$ & 55 & 78 \\
\hline 25 & Delete Data Universitas & 70 & 93 \\
\hline 26 & Melakukan logout sistem & 75 & 87 \\
\hline \multicolumn{4}{|c|}{ E-Recruitment Pelamar } \\
\hline 27 & Melakukan login sistem & 66 & 94 \\
\hline
\end{tabular}

\begin{tabular}{|c|c|c|c|}
\hline 28 & $\begin{array}{l}\text { Melakukan proses } \\
\text { tracking }\end{array}$ & 72 & 88 \\
\hline 29 & $\begin{array}{l}\text { Memilih tanggal, bulan, } \\
\text { dan tahun untuk Psikotes } \\
\text { yang diinginkan }\end{array}$ & 64 & 86 \\
\hline 30 & $\begin{array}{l}\text { Memilih tanggal, bulan, } \\
\text { dan tahun untuk Interview } \\
\text { HR dan user yang } \\
\text { diinginkan }\end{array}$ & 65 & 83 \\
\hline 31 & $\begin{array}{l}\text { Memilih tanggal, bulan, } \\
\text { dan tahun untuk Medical } \\
\text { Check-Up (MCU) yang } \\
\text { diinginkan }\end{array}$ & 70 & 92 \\
\hline 32 & Melakukan logout sistem & 57 & 86 \\
\hline \multicolumn{4}{|c|}{ E-Recruitment Marketing } \\
\hline 33 & Melakukan login sistem & 67 & 90 \\
\hline 34 & Unggah iklan di homepage & 54 & 88 \\
\hline 35 & Melakukan logout sistem & 70 & 91 \\
\hline & Rata-Rata & 2194 & 2934 \\
\hline
\end{tabular}

Berdasarkan Tabel 5 hasil pengujian dengan PageSpeed Insight menunjukkan bahwa rata-rata skor performa aplikasi penilaian kualitas aplikasi web $e$ recruitment jika diakses dengan perangkat mobile adalah 62.686 atau "Kurang". Sementara jika diakses menggunakan perangkat Desktop maka rata-rata skornya adalah 83.829 atau "Baik".

\section{Pengujian Faktor Maintainability}

TABEL 6

ANALISIS HASIL PENGUJIAN MAINTAINABILITY

\begin{tabular}{|c|c|c|c|}
\hline No. & Aspek & $\begin{array}{c}\text { Aspek } \\
\text { yang } \\
\text { Dinilai } \\
\end{array}$ & $\begin{array}{l}\text { Hasil yang } \\
\text { Diperoleh }\end{array}$ \\
\hline 1. & $\begin{array}{l}\text { Instru } \\
\text { men } \\
\text { tation }\end{array}$ & $\begin{array}{l}\text { Terdapat } \\
\text { peringatan pada } \\
\text { aplikasi untuk } \\
\text { mengidentifikasi } \\
\text { kesalahan. }\end{array}$ & $\begin{array}{l}\text { Memberikan pesan } \\
\text { kesalahan } \\
\text { (peringatan) saat } \\
\text { aplikasi gagal } \\
\text { mengeksekusi } \\
\text { fungsi tertentu. }\end{array}$ \\
\hline 2. & $\begin{array}{l}\text { Consis } \\
\text { tency }\end{array}$ & $\begin{array}{l}\text { Penggunaan } \\
\text { satu bentuk } \\
\text { rancangan pada } \\
\text { seluruh } \\
\text { rancangan } \\
\text { aplikasi. }\end{array}$ & $\begin{array}{l}\text { Memiliki rancangan } \\
\text { yang sama dan } \\
\text { memiliki tampilan } \\
\text { yang konsisten dari } \\
\text { satu halaman ke } \\
\text { halaman lain. }\end{array}$ \\
\hline 3. & $\begin{array}{l}\text { Simpli } \\
\text { city }\end{array}$ & $\begin{array}{l}\text { Kemudahan } \\
\text { dalam } \\
\text { pengelolaan, } \\
\text { perbaikan, dan } \\
\text { pengembangan } \\
\text { aplikasi. }\end{array}$ & $\begin{array}{l}\text { Mudah diperbaiki } \\
\text { dan dikembangkan } \\
\text { karena dibuat } \\
\text { dengan skema } \\
\text { Model-View } \\
\text { Controller } \\
\text { (MVC) dan bersifat } \\
\text { modular sehingga } \\
\text { penambahan atau } \\
\text { maintenance pada } \\
\text { suatu modul tidak } \\
\text { akan mempengaruhi } \\
\text { modul lainnya. }\end{array}$ \\
\hline
\end{tabular}




\section{Pengujian Faktor Portability}

Berdasarkan hasil pengujian, aplikasi web dapat diakses dengan baik dan tidak ditemukan error menggunakan berbagai macam web browser sehingga memenuhi faktor portability. Web browser Desktop yang digunakan yaitu Mozilla Firefox, Google Chrome, Internet Explorer, Safari, Opera dan web browser mobile yaitu Firefox Mobile, Chrome Mobile, Opera Mini, Dolphin Browser, dan UC Browser.

\section{IV.PENUTUP}

\section{A. Kesimpulan}

Berdasarkan penelitian yang telah dilakukan, maka dapat diambil kesimpulan bahwa aplikasi web $e$ recruitment mampu berjalan dengan baik dengan beberapa revisi dari ahli rekrutmen dan ahli pemrograman. Berdasarkan uji kualitas aplikasi web $e$ recruitment didapat hasil nilai persentase faktor functionality $96.79 \%$ (sangat tinggi). Pada pengujian faktor reliability didapat hasil 100\% (sangat tinggi) dengan pengujian menggunakan tool dari LoadStorm dan LoadImpact. Hasil pengujian dengan WAPT 8.1 untuk tiga metrik adalah sessions $100 \%$, pages $100 \%$, dan hits $100 \%$. Jadi pengujian pada faktor reliability menunjukkan nilai sangat tinggi. Hasil pengujian usability menggunakan metode kuesioner CSUQ adalah 5,3 dengan kategori layak. Hasil pengujian efficiency menggunakan GT Metrix (Yslow) menunjukkan rata-rata overall performance score 51 dengan grade D. Dengan demikian, hasil pengujian efficiency dengan GT Metrix (Yslow) menunjukkan hasil kurang. Sementara pengujian efficency menggunakan PageSpeed Insight menunjukkan nilai rata-rata untuk mobile 62.686 (kurang) dan desktop 83.829 (baik). Pengujian dari faktor maintainability menunjukkan bahwa aplikasi telah diuji dan memenuhi metrik maintainability yaitu instrumentation, consistency, dan simplicity. Kemudian dari sisi portability, aplikasi telah diuji menggunakan dengan beberapa web browser. Hasilnya aplikasi bisa diakses menggunakan semua web browser tersebut tanpa ada error sehingga aplikasi telah memenuhi faktor portability.

\section{B. Saran}

Aplikasi web e-recruitment dapat dikembangkan pada penelitian lebih lanjut dengan menambahkan fitur chat with applicant, di mana fitur tersebut juga dapat memposting information blast kepada pelamar yang telah dipilih pada aplikasi web e-recruitment admin. Selain itu, pada aplikasi dapat ditambahkan menu history, sehingga pelamar dapat melihat track process yang pernah dijalani pada proses rekrutmen sebelumnya. Pada menu setup perlu ditambahkan field periode iklan, sehingga penanyangan iklan dapat diatur.

\section{REFERENSI}

[1] Gat and S. Kosasi, "Pengembangan aplikasi e-recruitment dalam perekrutan karyawan," Jurnal Eksplora Informatika, vol. 3, no. 2, pp. 131-141, Mar. 2014

[2] M. Irsan, E. Yuliyasni, K. Nufus, S. Afrida, and E. Ratnasari, "Rancangan aplikasi e-recruitment pada PT. Kalila Indonesia," Prosiding Seminar Nasional Teknologi Informasi dan Komunikasi 2014 (SENTIKA 2014), 2014, pp. 429-435.

[3] N. Sharma, "Recruitment strategies: a power of e-recruiting and social media," International Journal of Core Engineering and Management (IJCEM), vol. 1, no. 5, pp. 15-35, Aug. 2014 .

[4] R. Ramaabaanu and M. Saranya, "Importance and problems of e-recruitment," International Journal of Research (IJR), vol. 1, no. 9, pp. 445-450, Oct. 2014.

[5] A. B. Holm, "The effect of e-recruitment on the recruitment process: evidence from case studies of three Danish MNCs," in Proceedings of the Third European Academic Workshop on Electronic Human Resource Management, 2010, pp. 91-111.

[6] M. A. Jabar, U. A. Usman, and A. Awal, "Assessing the usability of university websites from user's perspective," Australian Journal of Basic and Applied Sciences, vol. 7, no. 10, pp. 98-111, 2013

[7] T. W. Mebrate, "A framework for evaluating academic website's quality from students' perspective," M. S. thesis, Delft University of Technology, Netherlands, 2010.

[8] R. E. Al-Qutaish, "Quality models in software engineering literature: an analytical and comparative study," Journal of American Science, vol. 6, no. 3, pp. 166-175, Nov. 2010.

[9] Supriyono, V. A. Kristi, N. Kadir, J. Febriana, E. P. Rahayu, and H. P. Titania, "Penerapan ISO 9126 dalam pengujian kualitas perangkat lunak pada e-book," Jurnal Ilmu Komputer dan Teknologi Informasi, vol. 1, no. 1, pp. 9-13, Apr. 2019.

[10] V. Siren, N. Setiawan, and R. Rokhmawati, "Evaluasi kualitas perangkat lunak menggunakan ISO/IEC 9126-4 quality in use (studi kasus: FILKOM Apps)," Jurnal Pengembangan Teknologi Informasi dan Ilmu Komputer, vol. 3, no. 2, pp. 1625-1632, Feb. 2019.

[11] C. Kartiko, "Evaluasi kualitas aplikasi web pemantau menggunakan model pengujian perangkat lunak ISO/IEC 9126," Jurnal Nasional Teknik Elektro dan Teknologi Informasi (JNTETI), vol. 8, no. 1, pp. 16-23, Feb. 2019.

[12] Sugiyono, Metode Penelitian Kuantitatif, Kualitatif dan $R \& D$, Bandung: Alfabeta, 2011.

[13] J. Sauro and J. R. Lewis, Quantifying the user experience, USA: Elsevier, 2012. 